9. Lapka M., Vávra J., Sokolickova Z. Cultural Ecology: Contemporary Understanding of the Relationship Between Humans and the Environment. Journal of Landscape Ecology. 2012. № 5 (2). pp. 12-24. DOI: 10.2478/v10285-012-0050-z [in English].

10. 10. Pankina M.V., Khrustalyova C. M., Egarmin A. A., Shekhova N. V. Role of Design in the Consumer Culture Development: Ecological Context. International journal of environmental \& science education. 2016, Vol. 11. №. 16. pp. 8771-8780 [in English].

11. Story M., Kaphingst K., Robinson-O'Brien R., Glanz K. Creating Healthy Food and Eating Environments: Policy and Environmental Approaches. Annual Review of Public Health. 2008. Vol. 29. pp. $253-272$. https://doi.org/10.1146/annurev.publhealth.29.020907.090926 [in English].

12. Vakleva Z. About the category of ecological culture. Public sciences, art and culture. 2017. Vol. 4. pp. 257-261 [in English].

Стаття надійшла до редакції 02.11.2018 р.

УДК 008:[7.037.3:82.0]:[13:14 Кант

Вернигоренко Ольга Сергіївна, аспірантка Національної академії керівних

кадрів культури і мистецтв

ORCID 0000-0001-5704-7924

pozhar_olga@ukr.net

\title{
«ЗАРОЗУМІЛА МОВА» В РОСІЙСЬКОМУ ФУТУРИЗМІ ЯК «ЯВИЩЕ» ТА «РІЧ В СОБІ» ВІДПОВІДНО ДО «КРИТИКИ ЧИСТОГО РОЗУМУ» ІММАНУЇЛА КАНТА
}

Мета роботи: дослідити «зарозумілу мову» російського футуризму як «явище» та як «річ в собі» відповідно до філософської праці Іммануїла Канта «Критика чистого розуму», праці, яка присвячена визначенням джерел, принципів та меж наукового знання. Методологія дослідження полягає у застосуванні порівняльно-історичного, біографічного та психологічного методів. Наукова новизна. У роботі вперше подано культурологічно-філософське бачення проблеми «зарозумілої мови» (впровадження авторської словотворчості; вигадування нових слів які, на відміну від неологізмів, були позбавлені змісту й загального розуміння; мова, яка лежить поза межами розуму (В. Хлєбніков) в російському футуризмі відповідно до «Критики чистого розуму» I. Канта. Висновки. Образ об’єкта чи об’єкт як «явище» відповідно до «Критики чистого розуму» I. Канта - це завжди суб'єктивне відображення реальності, яке не несе інформацію про істинну сутність об’єкта. Різні точки зору щодо «зарозумілої мови», висловлені творцями й дослідниками російського футуризму, своєю багатогранністю й протилежністю наближують до повноти розуміння предмету дослідження - «зауму», i відкривають шлях для майбутніх наукових пошуків у цій темі.

Ключові слова: «чистий розум», «річ в собі», «явище», ноумен, футуризм, «зарозуміла мова», «заум». искусств

Вернигоренко Ольга Сергеевна, аспирантка Наџиональной академии руководящих кадров культуры и

«Заумь» в русском футуризме как «явление» и «вещь в себе» в соответствии с «Критикой чистого разума» Иммануила Канта

Цель работы: Исследовать «зумный язык» российского футуризма как «явление» и как «вещь в себе» в соответствии с философским трудом Иммануила Канта «Критика чистого разума», трудом, который посвящен определению источников, принципов и пределов научного знания. Методология. Методология исследования заключается в применении сравнительно-исторического, биографического и психологического методов. Научная новизна. В работе впервые представлены культурологическо-философское видение проблемы «заумного языка» (внедрение авторского словотворчества; придумывание новых слов которые, в отличие от неологизмов, были лишены смысла и общего понимания, язык, который лежит за пределами разума (В. Хлебников) в российском футуризме в соответствии с «Критикой чистого разума» Канта. Выводы. Образ объекта или объект как «явление» в соответствии с «Критикой чистого разума» И. Канта - это всегда субъективное отражение реальности, которое не несет информацию об истинной сущности объекта. Различные точки зрения на «заумный язык», высказанные авторами и исследователями русского футуризма, своей многогранностью и противоположностью приближают к полноте понимания предмета исследования - «зауми», и открывают путь для будущих научных изысканий в этой теме.

Ключевые слова: «чистый разум», «вещь в себе», «явление», ноумен, футуризм, «заумный язык», «заумь».

(C) Вернигоренко О. С., 2019 
Vernyhorenko Olga, graduate student at the National Academy of Culture and Arts

«Arrogant language» in Russian futurism as a «phenomenon» and as a «thing in itself» according to Immanuel Kant's "Critique of Pure Reason"

The purpose of the article. To study the «zaum» of Russian futurism as a «phenomenon» and as a «thing in itself» in accordance with the philosophical work of Immanuel Kant «Critique of Pure Reason», a work devoted to the definition of sources, principles and limits of scientific knowledge. Methodology. The methodology of the research is to apply comparative-historical, biographical and psychological methods. Scientific novelty. In the work, for the first time, the cultural-philosophical vision of the problem of «arrogant language» was introduced (the introduction of author's creation, the creation of new words, which, unlike neologisms, were deprived of meaning and general understanding; a language that lies outside the mind (V. Khlebnikov) in Russian futurism According to I. Kant, «Critique of Pure Reason». Conclusions. The image of an object or object as a «phenomenon» in accordance with «Critique of Pure Reason» by I. Kant is always a subjective reflection of reality, which does not bear information about the true essence of Object: Different points of view regarding «arrogant language», expressed by the creators and researchers of Russian futurism, with their versatility and opposite approach to the comprehensiveness of understanding of the subject of research - "zamoum", and open the way for future scientific research in this topic.

Key words: «pure mind», «thing in itself», «phenomenon», noumen, futurism, «arrogant language», «zaum».

Актуальність дослідження. Як один із напрямків авангарду, футуризм, який виник на початку $\mathrm{XX}$ ст. й синтезував у собі ідеї творчих новаторств французьких та італійських митців, швидко отримав широку підтримку у всій Європі і поза іiі межами. Фактично відразу після виходу в світ «Першого футуристичного маніфесту», що його створив Філіппо Марінетті, зачинатель нового культурно-мистецького напрямку у Франції й Італії, із поняттям «футуризму» знайомляться й російські митці. У 1909 р., у популярному журналі «Вісник літератури» (1909, №5) публікують російськомовний переклад маніфесту $[20,5]$. Відтоді футуризм почав набирати популярності серед представників творчої молоді Росії. Новий культурно-мистецький напрям передовсім підтримали поети й письменники, які, бажаючи творити нову літературу, наповнювали іiі різними творчими експериментами. Одним із таких була «зарозуміла мова» (впровадження авторської словотворчості; вигадування нових слів які, на відміну від неологізмів, були позбавлені змісту й загального розуміння; мова, яка лежить поза межами розуму (В. Хлєбніков).

Еволюційний шлях «зарозумілої мови», корені якого сягають початку минулого століття, триває і нині. Зокрема, російський «заум», як один із елементів творчого наповнення художніх текстів, уже подолав період активного побутування у поетико-прозових творах митців, і тепер виходить на новий щабель існування, стаючи предметом наукових дискусій філософів, культурологів, лінгвістів. Враховуючи перспективність заявленої теми дослідження, як такої, що потребує додаткового розгляду з позицій культурології, вважаємо іiї актуальною.

Постановка проблеми. Понад два століття тому зачинатель німецької класичної філософії I. Кант видав працю, яку сучасні дослідники називають головною у науковій творчості мислителя «Критику чистого розуму». За І. Кантом усі об'єкти, якими наповнений простір (наявність якого мислиться за умови апріорного співіснуванням з часом) варто розглядати не тільки як «речі в собі», але і як «явища», які філософ називає «невизначеними предметами емпіричного споглядання» $[8,63]$. «Явище» завжди знаходиться у полі пізнання розумом, а будь-які пояснення - це тільки те, що ми знаємо про явище, тобто продукт діяльності нашого розуму, який може відрізнятися від сутності самого явища. У «Критиці чистого розуму», торкаючись питань статусу мови у бутті, І. Кант визначав людину головним дослідником мови й буття у цілому.

На початку XX ст. німецький філософ М. Гайдегrер, у науковій діяльності якого питання відносин мови і буття посідали одне 3 центральних місць, означив мову як «дім буття». За мислителем, буття визначає своє ставлення до себе самого й до людини. У такому випадку людина приречена бути захисником мови (М. Гайдеггер), але не її дослідником.

Уже в першій половині XX ст. французький соціолог, теоретик мистецтва й письменник Жорж Батай, у праці «Внутрішній досвід» [1], яка у цілому присвячена темі містицизму, торкається й питань взаємовідносин мови й буття. За мислителем, Людина може бути одним цілим зі Словом, за допомогою якого мовить Буття [1, 36-37].

Погляди дослідників на питання статусу мови у бутті, своєю протилежністю загострюють проблему дослідження, але разом з тим, спонукають до пошуку відповідей на питання чим була «зарозуміла мова» у творах російських футуристів: емоцією, яка породжувала звук чи спланованим філософсько-естетичним експериментом (Б. Енгельгардт), звуконаслідуванням (О. Туфанов) чи залишком звуку, який у такому вигляді перенесений автором на папір (В. Шкловський)? Ми маємо справу із остаточною формою побутування «зауму», певною ціннісною енергією, яка через митців 
знаходила своє втілення в творах мистецтва, у даному випадку в літературі. Дослідження джерел «зарозумілої мови», iї природи і складає головну проблему нашого дослідження.

Аналіз попередніх досліджень і публікацій. Поняття «футуризму», а відтак і «зарозумілої мови» як складової цього явища у літературно-мистецькому просторі Росії початку ХХ ст., ставало об'єктом дослідження російських науковців. Так, одним із перших дискусію про походження футуризму в Росії розпочав російський поет, перекладач, учасник футуристичних груп, редактор видань футуристів Вадим Шершеневич. У 1913 р. автор видав книгу під назвою «Футуризм без маски» [27], у якій не тільки окреслив походження новітнього культурно-мистецького напрямку в Росії, а й дав характеристику існуючим на той час петербурзьким егофутуристам та московським кубо-футуристам. Батьківщиною футуризму В. Шершеневич називає Італію. Щодо російського футуризму зазначає наступне: «Звісно, як і будь-який напрямок, він постав у блазнівському гримі, 3 дзвіночками, i, можливо, ще зарано пояснювати його і робити будь-які висновки. Надто багато ще бутафорського, епатажного у футуризмі» $[27,55]$. Попри це, автор звертає увагу читача на проблеми Слова, форми і змісту, наповнення російських футуристичних поезій.

Творчість російських митців-новаторів стала предметом дослідження російського i радянського художника і мистецтвознавця М. Радлова. У своїй статті «Про футуризм» [19] він, як і попередній автор, наголошує на європейському, а саме італійському, походженні новаторського напрямку в мистецтві. М. Радлов, характеризуючи російський футуризм, зазначає: «Футуристів не можна було вигнати через острах пропустити. Їх потрібно було прийняти, про всяк випадок, але тільки настільки, щоб не бути розчавленим або скаліченим» $[19,18]$.

Уперше поняття «зарозумілої мови» (російською звучить як «заумный язык», «заумь»- авт.) до наукового обігу ввів поет, теоретик російського футуризму Велимир Хлєбніков [25]. За автором, «зарозуміла мова» - та, яка лежить поза межами розуму i «те, що в заклинаннях, заговорах зарозуміла мова переважає і витісняє розумну, доказує, що у неї особлива перевага над свідомістю, особливі права на життя поряд 3 розумною» $[25,174]$. Допускаючи одночасне існування в людині двох мов, розумної, яка мешкає в свідомості, та «зарозумілої», походження якої неможливо пояснити, останню відносимо до несвідомого (3. Фрейд) [24]. За 3. Фрейдом несвідоме породжує свідоме. Тобто, можемо припустити, що «зарозуміла мова» може мати статус протомови у концепції В. Хлєбнікова.

Російський поет-футурист В. Маяковський, який у власній творчості вдавався до застосування «зарозумілої мови», у статті «Про новітню російську поезію» $[17,365]$ розмірковує над значенням слова в літературі. Зокрема, автор зауважує, що головним досягнення російських футуристів станом на 1912 р., є, зокрема і те, що митці підтримують ідею «відродження первісної ролі слова» [17, 365]. Якщо припустити, що первісним завданням слова була передача інформації, то у даному випадку можемо говорити про звук, оскільки графічний символ, який передавав значення звуку, був вторинним. Проте уже через рік В. Маяковський у тезах до статті «Той, що прийшов сам» (1913 р.) [17, 365-366] наголошує, що слово виступає «проти мови (літературної та академічної), проти синтаксису, проти етимології» $[17,366]$. Слово (у широкому значенні), яке було проти етимології, було зручним: не знаючи його походження, сприймаючи його як таке, що існує саме по собі, без претензій на вміст у своєму смислі сторін, що відображали б його (слова) історичну тяглість і зв'язок з попередніми поколіннями, а отже таке слово легко втратити. Зрештою, це могло частково задовольнити мистецькі прагнення футуристів, які шукали і створювали нові слова.

Зрозуміти і певною мірою пізнати «зарозумілу мову» як явище одним із перших намагався російський теоретик мистецтва, який пізніше звертався до «зауму» як поет, Олександр Туфанов у праці «До зауму» [22]. Автор висловлює думку, що в основі «зарозумілої мови» лежить не слово, як поєднання фонеми й морфеми, а саме звук, який «близький до природи» й виступає їі відображенням у відтворенні людиною.

Дещо іншої точки зору щодо «зауму» притримувався російський літературознавець Борис Енгельгардт. У праці «Формальний метод в історії літератури» [29] автор зауважує, що «зарозуміла мова» була спробою: «створення комунікацій суто емоційного типу, і поняття «зарозумілості» втрачало будь-який смисл і будь-яку даність» [29, 66-67]. Книга Б. Енгельгардта вийшла в 1927 р., коли футуризм поступово почав втрачати ознаки незалежності й потрапляти під вплив радянської ідеології, тож і «заум» на той період 3'являвся частіше в роботах літературознавців, ніж самих літераторів. Тому Б. Енгельгардт зауважував, що: «поняття «зарозумілої мови» повинно розглядатися як умовний прийом естетичного аналізу літературної пам'ятки, до того ж прийом, який має вагоме методологічне підгрунтя» [29, 68].

Темі «зарозумілої мови» присвятили свої роботи сучасні російські дослідники, зокрема філолог, фахівець $з$ проблем авангарду Ю. Гірін [4, 54-68], [5, 333-345], доктор педагогічних наук 
Є. Коротаєва [12, 39-47], лінгвіст Н. Фатєєва [23, 46-56], літературознавець та фольклорист Г. Левінтон [16] та ін.. Серед українських науковців називаємо Ю. Коваліва [10, 14-20], І. Браїлка [2, 18-21], О. Вялікову [3, 31-38], М. Кабиш [7, 118-123] та ін.

Мета дослідження. Дослідити «зарозумілу мову» російського футуризму як «річ в собі» та як «явище» відповідно до філософської праці Іммануїла Канта «Критика чистого розуму», праці, яка присвячена визначенням джерел, принципів та меж наукового знання.

Виклад основного матеріалу. 19 квітня 1913 р. Олексій Кручоних випустив листівку «Декларація слова як такого», у якій виклав основні, на думку автора, функції слова у мові. Листівка, яка за формою викладення матеріалу, зовні була подібною на декларацію, де кожний вислів, що стосувався певних морфемних функцій і починався з нового рядка із власним номером (але не попорядку, а починаючи з №4), усе ж більше нагадувала філософське есе. Основні ідеї «Декларації» зводилися до того, що сучасна авторові російська мова - застаріла і не може повністю задовольняти потреб нового покоління поетів, письменників, оскільки «Слова помирають, а світ завжди юний» [20, 71]. Крім того, автор наголошує на тому, що «думка і мова не встигають за переживанням натхненного, тому митець може висловлюватися не тільки загальною мовою (поняттями), але й особистою (митець індивідуальний), і мовою, яка не має окресленого значення, (не застиглою), «зарозумілою мовою». (Приклад: го оснег кайд и т. д.» $[20,71]$. Подальші теоретичні розробки й широке застосування «зарозумілої мови» у поетичній практиці російських митців окреслювало поле для дискусій як у середовищі теоретиків футуризму, так і серед прихильників й опонентів напрямку.

Перш, ніж перейти до означення поняття «зарозумілої мови», а також визначення приналежності «зауму» до «явища» чи «речі» в собі, відповідно до «Критики чистого розуму» I. Канта, варто спробувати дати відповідь на запитання що таке мова, і чим вона $є$ для людини, людського суспільства. Сучасний український мовознавець М. Кочерган зазначає, що мова - це «один із найвизначніших божественно-людських витворів, універсальне надбання людства й універсальна реальність суспільного існування» $[13,7]$. Не піддаючи сумніву два останні факти про мову, які наведенні у визначенні, апелюємо до першої частини речення. Так, М. Кочерган до окреслення поняття підходить 3 теологічної точки зору, що, на перший погляд, не характерно для мовознавства, але разом 3 тим, саме таке визначення підкреслює особливість мовного питання у сучасній науці, зважаючи на те, що допер науковці не мають чітких відповідей на питання про те, як з'явилася мова, обмежуючись лише певними теоріями чи гіпотезами [30].

Теологічний спосіб розуміння сутності й походження мови не $є$ достатньо науковопродуктивним й варто розглянути ці питання у площині філосфсько-культурологічних концепцій. Так, сучасний український філософ В. Сіверс зазначає, що: «Мова є універсальним ключем до скарбниці, яка зберігає у згорнутому знаково-символічному вигляді інформацію про всю людську культуру та історію i, власне, про життя людей як роду» $[21,111]$. Спробуймо проаналізувати «зарозумілу мову» з точки зору такого визначення.

Першою ознакою, вказаною у понятті, є універсальність. Зважаючи на наведені приклади «зауму» стає очевидним те, що він був позбавлений загальності й орієнтований виключно на вузьке коло осіб, теоретиків футуризму й прихильників новаторського напрямку.

Для прикладу наведемо декілька уривків з поезій, створених із застосуванням «зарозумілої мови». Так, В. Хлєбніков у збірці «Ляпас громадському смакові» публікує вірш «Кінь пржевальського». Подаємо цитату мовою оригіналу: «Бобэоби пелис губы // Вээоми пелись взоры / Піээо пелись брови // Ліэээй пелся обликь // Гзи-гзи-гзэо пелась цепь // Так на холсте каких-то соответствій // Вне протяженія жило Лицо» $[18,7]$. I якщо у В. Хлєбнікова використання вигаданих слів поєднувалося із зрозумілими й загальновживаними, то лідером у темі теоретичного обгрунтування й практичного застосування «зарозумілої мови» можемо вважати О. Кручоних. Зокрема, автор закликав молодих митців перейти до «зауму», вважаючи це єдиним порятунком для оновлення літератури й поезії зокрема. Для прикладу подаємо уривок з вірша О. Кручоних, опублікований в альманасі «Апокаліпсис в російській літературі» [14]: «Плясовая // кваб // тарад // тара - пин // пирк! // квара // куаба // ував // вабакр! // трбрк... // брктр // кр...» [14, 38]. Очевидним виявляється беззаперечний факт незрозумілості морфологічних сполучень, поданих у рядку. Про «зарозумілість» поки не йдеться.

Інша характеристика, зазначена у визначенні, це знаково-символічна форма існування мови. В. Хлєбніков у статті «Художники світу» говорить про першочергове призначення мови в житті людства: «Мови зрадили своєму славному минулому. Колись, коли слова руйнували ворожнечу i робили майбутнє прозорим і спокійним, мови, крокуючи по східцях, об'єднували людей 1) печери, 2) села, 3) племені, родові союзи, 4) держави - в один розумний світ. Дикун розумів дикуна $\mathrm{i}$ 
відкладав убік сліпу зброю» $[25,153]$. У статті В. Хлєбніков не тільки окреслює етапи появи мови, але й говорить про так званий «загальнолюдський алфавіт» $[25,154]$, який позначає звуки, що у всіх мовах мають однакове значення. Для прикладу автор подає звуки, передані на письмі 3 використанням літер слов'янської абетки. Так, В. Хлєбніков зазначає: «Поки що, не доказуючи, я стверджую: 2) Що Х означає замкнуту криву, що відділяє перепоною положення однієї точки, рух до неї іншої точки (захисна межа); 4) Що М означає розпад деякої величини на нескінченно малі частини, у цілому рівні першій величині» [25, 154-155]. Крім того, у статті подані авторські графічні зображення звуків, які, на думку В. Хлєбнікова, можуть мати універсальний характер і слугувати новим видом письма й мови, назва якій «зарозуміла» $[25,158]$.

Повертаючись до знаково-символічності мови, й беручи до уваги пропоновану В. Хлєбніковим форму вираження нової, як зауважує автор, світової мови - «зарозумілої», наголошуємо на декількох аспектах, які спростовують теорію універсальності, доступності та альтернативності зауму. По-перше, авторська розробка В. Хлєбнікова не могла претендувати на універсальність. Хоча б, з огляду на те, що у концепції «нової світової мови» автор не дає чітких рішень щодо реалізації плану поширення цієї «мови» серед населення. По-друге, надаючи звукам певного буквеного обрамлення, послуговуючись виключно слов'янською абеткою, автор таким чином вкотре залишав під питанням універсальність «зарозумілої мови», оскільки у концепції було відсутне пояснення іншими мовами (наприклад Хінді, арабською, китайською, англійською тощо). По-третє, обрати альтернативну мову означало б для Людини втрату зв'язку 3 попередніми поколіннями. У цьому не було потреби. Отже, з точки зору знаково-символічності, «зарозуміла мова» могла існувати й існувала лише у концепції В. Хлєбнікова, яка не мала потреби й шансів на реалізацію у повному вигляді.

Ще однією ознакою мови, визначеною В. Сіверсом, є те, що мова «зберігає у знаковосимволічному вигляді інформацію про всю людську культуру та історію i, власне, про життя людей як роду» $[21,111]$. Що могла передати «зарозуміла мова» у тому вигляді, в якому пропонував іiі втілити В. Хлєбніков? Пропоновану автором концепцію побутування «зауму» можемо вважати лише теоретичним експериментом, який був виконаний у дусі російського футуризму, проте не мав практичного застосування.

Умовними стежинами до соціо-онтологічного тлумачення «зарозумілої мови» можемо вважати концепції розкриття сутності «зауму», авторами яких є російська поетеса й художниця Олена Гуро та російський літературознавець Віктор Шкловський. Російський мистецтвознавець Є. Ковтун у статті, присвяченій творчості О. Гуро, подає іiі цитату, опубліковану в збірнику «Троє» [26] (автори: В. Хлєбніков, О. Кручених, О. Гуро): «Говорити слова, які ніби не співпадають зі смислом, але ті, які викликають певні образи, про які зовсім не говориться. Говорити набір слів, які не мають нічого спільного зі смислом, але які розбігом ритму говорять про наростання відчуттів» [11, 320]. О. Гуро у своїх поезіях вдавалася до застосування поєднання літер у слова, які можна вважати «зарозумілими», про що свідчить уривок з вірша поетеси «Фінляндія»: «Лес-ли, - озеро-ли? // Этоли?//Эх, Анна, Мария, Лиза, // Хей-тара! // Тере-дере-дере... Ху! // Холе-кулэ-нэээ» [6, 140]. Варто зауважити, що журнал «Троє» був присвячений пам'яті поетеси, адже вийшов друком після її смерті. Але поява ії імені поруч із теоретиками російського футуризму i, зокрема, «зауму» говорить не тільки про визнання, а й про значний вклад поетеси у розвиток ідеї «зарозумілої мови». «Заум» О. Гуро йшов пліч-о-пліч з їі ліричними поезіями і більше нагадує не словотворення, а спробу відтворити почуті звуки навколишньої дійсності: лісу, озера, шум міста тощо. Це дає нам підстави робити висновки про те, що в основі російського зауму у концепціях О. Кручоних, В. Хлєбнікова та О. Гуро був звук, який слову надавав другорядного значення.

В. Шкловський у статті «Про поезію та зарозумілу мову» [28, 45-58], характеризує «заум» у його виявах в творчості поетів, прозаїків, релігійних сектантів, магів. Таке об'єднання, на перший погляд, непоєднуваних груп людей, пояснюється тим, що в основі окремих поетичних творів i виголошуваних заклинань, лежить використання звуків, які, поєднуючись в умовні слова, часто були позбавлені раціонального змісту, виражаючи емоції. Автор статті висловлює припущення про те, що поети часто самі не розуміють своїх віршів (зарозумілих), оскільки «часто і вірші з'являються в душі поета у вигляді звукових плям, які не втілилися в слово. Пляма то наближається, то віддаляється i, нарешті, висвітлюється, співпадаючи зі співзвучним словом» [28, 53].

Цікаве спостереження щодо природи «зауму» знаходимо в концепціях О. Гуро та В. Шкловського. Обоє авторів звертають увагу на незрозумілість звуку, який з'являється в свідомості (а чи підсвідомості) митця. У цьому випадку маємо справу із «заумом» як «річчю в собі». Тоді як «зарозуміла мова» як явище проявляється в той момент, коли поет незрозуміле для нього самого 
перекладає в текстову форму, яка провокує іще одну сторону цього полілогу, - читача, на створення власних образів прочитаного. А це спонукає нас поглянути на «заум» як на ноумен відповідно до визначення, даного І. Кантом. За мислителем, ноумен - це «річ, яка повинна мислитися не як предмет чуттів, а як річ сама по собі (виключно через чистий розсудок)» [9, 192]. «Зарозуміла мова» як ноумен у негативному значенні (тобто, коли не $\epsilon$ об'єктом нашого чуттєвого споглядання) міститься у поезіях В. Хлєбнікова, О. Кручоних, О. Гуро, цитати з творів яких були наведені в тексті. «Зарозуміла мова» як ноумен у позитивному значенні (як об'єкт виключно інтелектуального споглядання, позбавленого чуттєвого) частково виявляється у критичних i наукових працях, присвячених проблемам «зауму». Оскільки науковець, керуючись принципом об'єктивізму, змушений розглядати досліджувані ним предмети і явища незалежно від власного емоційного, чуттєвого ставлення до них. Утім, не відкидаючи людського фактору й частки суб' єктивізму, яка притаманна для будь-якого дослідження, зауважуємо, що пізнання сутності предметів шляхом суто інтелектуального споглядання неможливе, принаймні для людського суспільства. Тоді як «зарозуміла мова» як позитивний ноумен може бути досліджена в майбутньому за допомогою Штучного Інтелекту, який, як відомо, сприйматиме світ через призму суто інтелектуального, позбавленого чуттєвості й емоційності, споглядання речей. Тобто так, про яке I. Кант понад два століття тому говорив як про неможливе й таке, що «є нам чужим, і навіть його можливості ми не можемо збагнути» $[9,191]$.

Звертаємо увагу на те, що І. Кант, у праці «Критика чистого розуму», власне про так званий практичний (або спекулятивний) розум говорить наступне: «Розум бачить тільки те, що сам створює за власним планом» $[8,21]$. Якщо продовжити розгляд «зарозумілої мови», відповідно до міркування Іммануїла Канта про існування «чистого розуму», (за допомогою якого людина пізнає світ, відкидаючи можливості пізнання через чуттєве споглядання та засоби розсудку), то «заум», саме у російському футуризмі (оскільки подібне явище буде відоме і для українського напрямку), постає у декількох варіантах: як ноумен (в позитивному і негативному значеннях), як «річ у собі», та як «явище». Спробуймо розглянути «зарозумілу мову» відповідно до наведених визначень почергово.

«Зарозуміла мова» як «річ в собі», частково мала місце у творчості теоретика російського футуризму Олексія Кручоних, оскільки автор одразу пише, використовуючи незрозумілі для читача слова, не даючи ним жодних пояснень. Наведемо цитату із «Декларації слова як такого»: «У мистецтві можуть бути недозволені дисонанси - «неприємні для слуху», адже у нашій душі $є$ дисонанс, яким і дозволяється перше. Приклад - дир бул щил і т. д.» [20, 72]. Подібні вислови автор використовував і в статті «Аполлон у сварці (живопис у поезії)» [15, 289-295]. Крім того, тексти, побудовані засобами такої мови мають вторинний характер, адже російський «заум» не створив власну знакову одиницю, що притаманно для самостійної мови, а послуговувався вже існуючими, загальновідомими літерами. Виключення становить авторська концепція зауму В. Хлєбнікова.

За I. Кантом, «речі в собі» $є$ елементами апріорних (таких, що передують будь-якому досвіду пізнання світу) чуттєвих форм - часу й простору. Для «речей в собі» характерне об'єктивне самостійне існування, незалежне від суб'єктивного відображення в людській свідомості. Натомість, у випадку «зарозумілої мови» ми отримуємо протилежне: «заум», у поетичному обрамленні в творчості представників російського футуризму, своїм існуванням завдячує Людині, як своєму творцю і носію. У такому разі Людина може не тільки пояснити, чим $є$ «зарозуміла мова», а й окреслити причини іiі появи. Як «річ в собі» «зарозуміла мова» постає у згадуваній концепції В. Хлєбнікова, який «заум» розглядає як протомову, що за основу містить звук. Суто теоретично існування «зарозумілої мови» у такому вигляді можливо, але до моменту появи у цій системі Людини, яка сприймає почуте й адаптує до власних потреб шляхом відтворення, чи то у формі імітації почутих звуків (вигуків тощо), чи у графічних позначеннях, як на це вказують перші ознаки людської писемності. Але в такому разі, не йтиметься про «заум» у футуристичних поезіях авторів початку ХX ст., оскільки між останніми і носіями протомови уже міститься величезна прірва. Отже, використання поєднання звуків з метою надання власним текстам незрозумілості чи зарозумілості насправді провокує на думку про цілком усвідомлений крок, який робили автори для популяризації своєї творчості, що є цілком зрозумілим 3 точки зору прагнення до набуття рис індивідуальності, пізнаваності, зрештою визнання.

«Зарозуміла мова» як «явище», відповідно до «Критики чистого розуму» І. Канта постає у концепціях дослідників «зауму», які були цитовані в тексті дослідження. Кожен з авторів висловлює власне бачення на проблему й намагається дати пояснення фактам, які вже відбулися й різноманіття версій походження «зарозумілої мови» лише вказує на неоднозначність ії̈ природи й походження.

Висновки. «Критика чистого розуму» I. Канта як праця, яка присвячена визначенням джерел, принципів та меж наукового знання, стала центральною роботою, через яку ми досліджуємо 
«зарозумілу мову» в російському футуризмі як «явище», як «річ в собі» та як «ноумен». Відповідно «зарозуміла мова» як «явище» постає у вигляді теорій походження «зауму», що їх пропонують науковці. Тоді як «зарозуміла мова» як «річ в собі» скеровує вченого, який береться за розкриття теми «зауму», поглянути на предмет дослідження через пізнання його сутності. Але I. Кант говорить про те, що сутність речі завжди залишається всередині її самої. У такому випадку проблема пізнання й інтерпретації «зауму» 3 наукової точки зору доповнюється декількома аспектами, які ускладнюють пояснення походження й сутності «зарозумілої мови» (відповідно до «Критики чистого розуму»). За I. Кантом, ми можемо пізнавати лише предмети чуттєвого досвіду, в інакшому випадку ми просто мислимо предмети, без можливості їх пізнання. Тоді «зарозуміла мова», як предмет чуттєвого досвіду і як «річ в собі», стаючи об'єктом наукового дослідження, опиняється у центрі певного замкнутого кола, за межами якого власне науковець, який, досліджуючи їі («зарозумілої мови») сутність, змушений керуватися апріорними (такими, що передують досвіду) науковими принципами й методами, які, проте, повинні бути строго доказовими (I. Кант). Так, науковці, через подання власних концептуальних бачень походження й природи «зарозумілої мови», якщо і не дають вичерпних відповідей на питання чим був «заум» у російському футуризмі, то принаймні наближають нас до усвідомлення беззаперечного факту: «зарозуміла мова» повинна розглядатися у співвідношенні понять «Буття - Мова - Людина». Найближче до вирішення цього питання підійшли російська поетеса й художниця О. Гуро та російський літературознавець В. Шкловський, які першоелементом «зарозумілої мови» вважали певний вид ціннісної енергії, який шляхом емоційних варіативних наростань в свідомості, а чи й підсвідомості особистості, (поетів, релігійних сектантів, магів В. Шкловський), знаходив вихід назовні у втіленні в звуці, і вже пізніше в графічному елементі літері, складі, слові.

Отже, «зарозуміла мова», як особливий вид мови, постає «річчю в собі» відповідно до «Критики чистого розуму» I. Канта. I, з одного боку, не піддається пізнанню. Але за мислителем людина - дослідник мови й буття, і якщо «заум» досліджувати як частину мови, це можна вважати першою сходинкою на шляху до розуміння «зарозумілого», певних «сингалів» буття, які до цього вважалися незрозумілими, нерозгаданими. М. Гайдеггер, який мову визначає домом буття, тільки посилює роль Людини, як захисника мови (М. Гайдеггер). I найбільше нас наближає до питання можливості зрозуміти «зарозуміле» Ж. Батай, за яким Людина і Слово - єдине ціле.

Пропоноване дослідження - це не тільки спроба розглянути «заум» в російському футуризмі як «явище», «річ в собі» та як «ноумен» відповідно до «Критики чистого розуму» I. Канта, а й спроба довести, що відповідно до концепцій співвідношення «Буття - Мови - Людини», авторами яких $\epsilon$ I. Кант, М. Гайдептер та Ж. Батай, «зарозуміла мова» може бути об’єктом пізнання, і в подальшому, шляхом майбутніх напрацювань з цієї проблематики, претендувати на роль зрозумілої. У цьому і полягає новизна дослідження.

\section{Лimepamypa}

1. Батай Ж. Внутренний опыт. Пер. с франц., послесловие и комментарии С. Л. Фокина. СПб.: Аксиома, Мифрил, 1997. 336 с.

2. Браїлко І. М. Словесні модифікації в поезії Михайля Семенка. Культура слова. К., 2000. Вип. 55-56.

3. Вялікова О. О. Типологія креолізованих віршованих текстів. Вісник Київського національного лінгвістичного університету. Сер. Філологія. К., 2014. Т. 17. С. 31-38.

4. Гирин Ю. Н. Онтологизация знака в культуре авангарда. Вопросы философии. Москва, 2012. № 11.

5. Гирин Ю. Н. Философия искусства авангарда. Вопросы эстетики и теории искусства XX века. М.: Госсударвстенный Институт Исскуствознания, 2018. № 16. С. 333-345.

6. Гуро Е. Небесные верблюжата. Избранное. Спб.: Лимбус Пресс, 2001. 244 с.

7. Кабиш М. Ю. Фоностилістичне інструментування творів українськими поетами - представниками літературних угруповань початку ХХ ст. Науковий часопис НПУ ім. М. П. Драгоманова. Серія 8. Філологічні науки (Мовознавство). К.: Вид-во НПУ ім. М. П. Драгоманова, 2012. Вип. 4. С. 118-123.

8. Кант И. Сочинения. В 8-ми т. М.: Чоро, 1994. Т. 3. 741 с.

9. Кант І. Критика чистого розуму. Пер. з нім. та приміт. І. Бурковського. К.: Юніверс, 2000. 504 с.

10. Ковалів Ю. І. Візуальна поезія Михайля Семенка. Літературознавчі студії. 2013. Вип. 39(2). С. 14-

20.

11. Ковтун Е. Ф. Елена Гуро: Поэт и художник. Памятники культуры. Новые открытия. Письменность. Искусство. Археология: Ежегодник. 1976. М., 1977. С. 317-327.

12. Коротаева, Е.В. Заумь в авангардной эстетике и фольклоре. Русская речь. 2015. № 1. - С.39-47

13. Кочерган М. П. Загальне мовознавство: підручник. К.: ВЦ «Академія», 2010. 464 с. 
14. Крученых А. Е. Апокалипсис в русской литературе. Чорт и речетворцы. Тайные пороки академиков. Слово, как таковое. Декларации. - М.: Тип. ЦИТ, 1923 - 46 [2] с.; ил.

15. Крученых А. Е. К истории русского футуризма: Воспоминания и документы. М.: Гилея, 2006. $458 \mathrm{c}$.

16. Левинтон Г. Статьи о поэзии русского авангарда. Helsinki: Unigrafia, 2017. 275 с.

17. Маяковский В. Полное собрание сочинений в 13-ти т. Москва: Государственное издательство художественной литературы, 1955. Т. 1. 463 с.

18. Пощёчина общественному вкусу. М.: Изд. Г. Кузьмина, 1913. 112 с.

19. Радлов Н. Э. О футуризме. Б. м.: Salamandra P. V. V., 2015. 78 с.

20. Русский футуризм: Стихи. Статьи. Воспоминания / Сост. В. Н. Терёхина, А. П. Зименков. СПб.: ООО «Полиграф», 2009. 832 с.

21. Сіверс В. А. Філософія науки: навч. посіб. Київ: Національна академія керівних кадрів культури $і$ мистецтв, 2017. 144c.

22. Туфанов А. К зауми. Фоническая музыка и функции согласных фонем. С портр. работы худ. И. Нефедова. Б.м.: Salamandra P. V. V., 2012. 81 с., ил.

23. Фатеева Н. А. Неологизмы-термины как элементы индивидуальной «поэтической филологии»: возможность словарного представления. Известия РАН. Серия литературы и языка, 2012. Т. 71. № 5. С. 46-56.

24. Фрейд 3. Введение в психоанализ: Лекции 1-15/ пер. с нем. Г.В. Барышниковой; под ред. Е.Е. Соколовой и Т.В. Родионовой. СПб.: Издательский Дом «Азбука-классика», 2007. 480 с.

25. Хлебников В. Собрание сочинений: В 6 тт. Москва: ИМЛИ РАН, 2005. Т. 6. Кн. 1. - 448 с.

26. Хлебников В., Крученых А., Гуро Е. Трое. СПб.: Журавль, 1913.96 с.

27. Шершеневич В. Футуризм без маски. Компилятивная интродукция. М.: Тип. Акц. О-ва печ. и издат. дела «Московск. Издат.», 1913. 106 с.

28. Шкловский В. Б. Гамбургский счет: Статьи - воспоминания - эссе (1914-1933). М.: Советский писатель, 1990. 544 с.

29. Энгельгардт Б. М. Формальный метод в истории литературы. Ленинград: «AKADEMIA», 1927. $118 \mathrm{c}$.

30. Якушин Б.В. Гипотезы о происхождении языка. М.: Наука, 1984. 136 с.

\section{References}

1. Bataille, J. (1997). Internal experience. SPb.: Axiom, Mithril [in Russian].

2. Brailko, I. V. (2000). Verbal modifications in the poetry of Mikhail Semenko. Culture of the word, 55-56, 18-21 [in Ukrainian].

3. Vyalikova, O. (2014). Typology of Creation of Texts. News of Kyiv National Scientific and Technical University. Ser. Philology, 14, 31 - 38 [in Ukrainian].

4. Girin, Yu. N. (2012). Ontologization of the sign in avant-garde culture. Questions of philosophy. Moscow, 11. P. 54-68 [in Russian].

5. Girin ,Yu. N. The philosophy of avant-garde art. Issues of aesthetics and theory of art of the twentieth century. State Institute of Art Studies, 16, 333-345 [in Russian].

6. Guro, E. (2001). Celestial camels. Favorites. Spb.: Limbus Press [in Russian].

7. Kabish, M. (2012). Background-style instrumentation works of Ukrainian poets - representatives of literary groups early twentieth century. Science magazine named NEA. M. P. Dragomanov, Series 8 Philology (Linguistics): Coll. Science. Labor, Vol. 4, 118 - 123. K .: Izd NEA them. M. P. Dragomanov [in Ukrainian].

8. Kant, I. (1994). Works. In 8 volumes. V.5. Moscow: Choro [in Russian].

9. Kant, I. (2000). Criticism of pure reason. K.: Universe [in Ukrainian].

10. Kovaliv, Y. (2013). Visual Poetry Semenko. Literary Studies, 39 (2), 14 - 20 [in Ukrainian].

11. Kovtun, E. F. (1977). Elena Guro: Poet and Artist. Monuments of culture. New discoveries. Writing. Art. Archeology: Yearbook, 1976, 317-327 [in Russian]. Russian].

12. Korotaeva, E. V. (2015). «Zaum» on avant-garde aesthetics and folklore. Russian speech, 1, 39-47 [in

13. Kochergan, N. M. (2010). General linguistics: a textbook. K.: VT «Akademiya» [in Ukrainian].

14. Kruchenykh, A. (1923). Apocalypse in Russian literature. The devil and the recheepters. Secret defects of academics. The word as such. Declaration. Moscow: Type. CIT [in Russian].

15. Kruchenykh, A. (2006). On the history of Russian Futurism: Memoirs and Documents. N. Gurianova (Ed.). Moscow: Gilea [in Russian].

16. Levinton, G. (2017). Articles about the poetry of Russian avant-garde. Helsinki: Unigrafia [in Russian].

17. Mayakovsky, V. (1955). Complete Works in 13 volumes. Moscow: State Fiction Publishing House, Volume 1 [in Russian].

18. Slap the public taste. (1913). M.: Izd. by G. Kuzmin [in Russian].

19. Radlov, N. E. (2015). About futurism. B. m.: Salamandra P. V. V. [in Russian].

20. Terekhina, V. N. \& Zimenkov, A. P. (Eds). (2009). Russian futurism: Poems. Articles. Memories. SPb.: LLC Polygraph [in Russian].

21. Sivers, V. A. (2017). Philosophy of science. Kyiv: National Academy of Culture and Arts [in Ukrainian]. 
22. Tufanov, A. (2012). To the zaum. Background music and the functions of consonant phonemes. With the portrait. Work thin. I. Nefedova. (facsimile edition). B. m.: Salamandra [in Russian].

23. Fateeva, N. A. (2012). Neologisms-terms as elements of individual «poetic philology»: the possibility of a vocabulary presentation. Proceedings of the RAS. A series of literature and language, V. 71, № 5, 46-56 [in Russian].

24. Freud, Z. (2007). Introduction to psychoanalysis: Lectures 1-15. SPb.: Publishing House «AlphabetClassic» [in Russian].

Russian].

25. Khlebnikov, V. (2005). Collected Works: In 6 volumes. Moscow: IMLI RAS, Volume 6, Book. 1 [in

26. Khlebnikov, V., Kruchenykh, A., Guro, E. (1913). Three. SPb.: Crane [in Russian].

27. Shershenevich, V. (1913). Futurism without a mask. Compilation introduction. M.: Type. Ac About Pec. and publ. affairs «Moskovsk. Izdat.» [in Russian].

28. Shklovsky, V. B. (1990). The Hamburg Account: Articles - Memories - Essay (1914-1933). M.: Soviet writer [in Russian]. Russian].

29. Engelhardt, B. M. (1927). The formal method in the history of literature. Leningrad: AKADEMIA [in

30. Yakushin, B. V. (1984). Hypotheses about the origin of the language. M.: Science [in Russian].

Стаття надійшла до редакизї 30.11 .2018 p.

УДК $393.92(477.85)$

\author{
Козек Микола Іванович, \\ аспірант Київського національного \\ університету культури і мистецтв \\ ORCID 0000-0002-6119-561X \\ KozekMykola1@gmail.com
}

\title{
РЕГІОНАЛЬНІ ОСОБЛИВОСТІ ПОХОВАЛЬНОЇ ОБРЯДОВОСТІ НА БУКОВИНСЬКІЙ ГУЦУЛЬЩИНІ
}

\begin{abstract}
Метою дослідження $є$ виявлення та обгрунтування регіональних особливостей в поховальній обрядовості українців Буковинської Гуцульщини. Методологія дослідження полягає в застосуванні аналітичного, історичного, порівняльного методів, та грунтується на зборі інформації 3 респондентів Буковинської Гуцульщини. Наукова новизна. Виявлено нові риси в поховальній обрядовості притаманні українцям Буковинської Гуцульщини. Висновки. Досліджено, що в поховальній обрядовості на Буковинській Гуцульщині є усталена послідовність дій, яка передається з покоління в покоління. Гуцули вірять, що від належного дотримання та виконання предкових поховальних обрядових дій залежить добробут всієї родини, їх господарства. Не менше значення, ніж дотримання поховальних дій, мають обрядові дії, пов'язані із вшануванням культу предків, які мають велику духовну цінність для українців Буковини. Гуцули вірять, що їх померлі родичі впливають на перебіг подій в родині, вони можуть як допомагати своїм рідним, так і робити їм погані вчинки. За давнім віруванням буковинських гуцулів саме предки забирають своїх родичів на «той» світ, коли хтось з кревних помирає. Таким чином, предки на Буковинській Гуцульщині виступають посередниками між живим світом і світом мертвих.
\end{abstract}

Ключові слова: поховальні обряди, гуцули, культ предків, традиція, культура, вірування.

Козек Николай Иванович, аспирант Киевского национального университета культуры и искусств Региональные особенности погребальных обрядов на Буковинской Гуцульщине

Целью исследования является выявление и обоснование региональных особенностей в погребальной обрядности украинцев Буковинской Гуцульщины. Методология исследования заключается в применении аналитического, исторического, сравнительного методов, и основывается на сборе информации из респондентов Буковинской Гуцульщины. Научная новизна. Обнаружены новые черты в погребальной обрядности, присущие украинцам Буковинской Гуцульщины. Выводы. Доказано, что в погребальной обрядности на Буковинской Гуцульщине есть устоявшаяся последовательность действий, которая передается из поколения в поколение. Гуцулы верят, что от надлежащего соблюдения и выполнения предковых погребальных обрядовых действий зависит благосостояние всей семьи, их хозяйства. Не меньшее значение, чем соблюдение погребальных действий, имеют обрядовые действия, связанные с чествованием культа предков, которые имеют большую духовную ценность для украинцев Буковины. Гуцулы верят, что их умершие родственники влияют на ход событий в семье, они могут как помогать своим родным, так и делать им плохие поступки. По древнему верованию буковинских гуцулов, именно предки забирают своих родственников на «тот» мир, когда кто-то из

(C) Козек М. I., 2019 